\title{
The Use of Tubularized Incised Plate Urethroplasty to Repair Distal Hypospadias in A Peripheral State Hospital
}

\author{
Perifer Devlet Hastanesinde Distal Hipospadias Onarımında TIPU Kullanımı
}

\author{
(D) Arif Aydın1, (D) Mehmet Giray Sönmez1, (D) Mehmet Büyükşerbetçi2, (D) Remzi Salar3, (D Serkan Özcan4, (D) Yunus Emre Göğer1, \\ (D) Mehmet Balasar1 \\ ${ }^{1}$ Necmettin Erbakan University Faculty of Medicine, Department of Urology, Konya, Turkiye \\ 2Bigadiç State Hospital, Clinic of Urology, Balıkesir, Turkiye \\ 3 Mehmet Akif Inan Training and Research Hospital, Clinic of Urology, Şanlıurfa, Turkiye \\ 4 İzmir Katip Çelebi University Faculty of Medicine, Department of Urology, Izmir, Turkiye
}

\section{What's known on the subject? and What does the study add?}

Tubularized incised plate urethroplasty is a successful method in the treatment of hypospadias, and various medical therapies can be used to increase patient comfort in postoperative period. Tubularized incised plate urethroplasty is a surgical treatment of distal hypospadias in the periphery could also be performe and Glans-Urethral Meatus-Shaft and hypospadias objective scoring evaluation scores are useful evaluating the hypospadias and surgery results.

\begin{abstract}
Objective: Hypospadias is a congenital anomaly of the male urethra that is becoming increasingly prevalent. In this paper, we share the results of our series of 45 distal hypospadias cases treated with tubularized incised plate urethroplasty (TIPU) at a single center in Şanlıurfa, Turkiye.

Materials and Methods: Hypospadias repairs were made by two urologists who had completed their urology residencies at the same clinic in a state hospital. The TIPU technique was used for all 45 patients. To prevent bladder contractions and reduce anal itching during hospitalization, the patients were administered low-dose oxybutynin and $2 \mathrm{mg} / \mathrm{mL}$ hydroxyzine hydrochloride; they were also followed up postoperatively for a mean duration of 9.3 (6-12) months.

Results: The average age of the patients was $9.5 \pm 0.5(2-24)$ years. Ten patients had been circumcised previously, preoperative skin chordee was observed in 35, and none experienced preoperative complications. Postoperative catheterization lasted seven days. Postoperatively, one patient developed a fistula and two developed meatal strictures. No other complications were observed in the other patients.

Conclusion: Hypospadias is an anomaly frequently seen in pediatric urology practice and requires considerable attention and experience. TIPU is an ideal technique for correcting hypospadias, especially distal hypospadias, due to its low complication rate and favorable cosmetic results. Although hypospadias surgery requires experience, it can be done quite easily in peripheral hospitals by surgeons who have trained in clinics experienced in this field, provided that they follow the rules pertaining to surgery.
\end{abstract}

Keywords: Hypospadias, TIPU, Snodgrass method, Dystal hypospadias, Hypospadias surgery, GMS score, HOSE score

Öz

Amaç: Hipospadias son yıllarda prevalansı giderek artan konjenital bir anomalidir. Şanlıurfa'da tek merkezde tübülarize insize plak üretroplasti (TiPU) yapılarak tedavi edilen 45 olguluk distal hipospadias serimizin sonuçlarını paylaştık.

Gereç ve Yöntem: Hipospadias onarımları tek merkez devlet hastanesinde aynı klinikten uzmanlığını almış 2 adet ürolog tarafından gerçekleştirildi. Tüm hastalarda TiPU tekniği kullanıldı. Mesane kontraksiyonlarını ve anal kaşıntıyı azaltmak için hastanede kalış süresince hastalara düşük doz oksibutinin ve hidroksizin HCL $2 \mathrm{mg} / \mathrm{mL}$ verildi. Hastalar ortalama 9,3 (6-12) ay takip edildi.

Correspondence: Arif Aydın MD, Necmettin Erbakan University Faculty of Medicine, Department of Urology, Konya, Turkiye Phone: +90 5055566988 E-mail: aydinarif@gmail.com ORCID-ID: orcid.org/0000-0001-8691-090x Received: 05.11.2018 Accepted: 26.02.2019

Cite this article as: Aydın A, Sönmez MG, Büyükşerbetçi M, Salar R, Özcan S, Göğer YE, Balasar M. The Use of Tubularized Incised Plate Urethroplasty to Repair Distal Hypospadias in A Peripheral State Hospital. J Urol Surg 2019;6(3):231-237.

๑Copyright 2019 by the Association of Urological Surgery / Journal of Urological Surgery published by Galenos Publishing House. 
Bulgular: Toplam 45 distal hipospadiaslı hastaya cerrahi uygulandı. Hastaların ortalama yaşı 9,5£0,5'di (2-24). 10 hasta daha önce sirkumsizyon operasyonu geçirmişti. Otuz beş hastada preoperatif deri kordisinin olduğu görüldü. Ameliyat süresi $90 \pm 10 \mathrm{dk}$ idi. Peroperatif hiçbir hastada komplikasyon izlenmedi. Postoperatif kateterizasyon süresi 7 gündü. Postoperatif 1 hastada fistül, 2 hasta da meatal darlık tespit edildi. Bu hastalara lokal anestezi altında mea dilatasyonu yapıldı ve dilatasyon tarif edildi. Ancak hastaların mea dilatasyonunu aktif yapamadıkları ve mea darlığının tekrarlaması üzerine bu hastalara postop 3. ayda meatoplasti yapıldı. Diğer hastalar da fistül veya başka bir komplikasyon görülmedi.

Sonuç: Hipospadias çocuk ürolojisi pratiğinde sık görülen ancak tedavisi zahmetli, büyük dikkat ve tecrübe gerektiren bir anomalidir TiPU özellikle distal hipospadiaslarda komplikasyon oranı az olması ve daha güzel bir kozmetik görünüm elde edilmesi nedeniyle distal hipospadias cerrahisinde ideal bir tekniktir. Hipospadias cerrahisi tecrübe isteyen bir cerrahi olmakla birlikte bu konuda tecrübeli kliniklerde eğitimini tamamlamış hekimlerin cerrahi kurallara uymak zorunluluğu ile mecburi hizmette (periferde) gayet rahat yapabilecekleri bir cerrahidir.

Anahtar Kelimeler: Hipospadias, TiPU, Snodgrass yöntemi, Distal hipospadias, Hipospadias cerrahisi, GMS skor, HOSE skor

\section{Introduction}

Hypospadias, which occurs in approximately 1 out of 200300 live births, is a condition in which the urethra opens to the ventral side of the penis. It is the second most common congenital defect seen in males, after cryptorchidism, and its prevalence has doubled over the past 30 years. The initial diagnosis of hypospadias is typically made during the physical examination after birth. In hypospadias patients, there is a ventral skin deficiency with a dorsal foreskin hood and an abnormally located meatus, with varying degrees of ventral penile curvature $(1,2)$.

Since it is one of the cities in Turkey with highest birth rate, hypospadias is a common occurrence in Şanlıurfa, and thus hypospadias repair is one of the most common surgical procedures done by pediatric urologists. The aim of hypospadias repair is to create a functional urethra and a normal penile appearance with a meatus at the tip of the penis. Singlesession methods, such as urethral advancement, urethral plate tubularization [tubularized incised plate urethroplasty (TIPU), and Thiersch-Duplay], and urethral lengthening using a flap are standard treatments for distal hypospadias (3). In this paper, we share the results of our series of 45 cases of distal hypospadias treated with TIPU at a single center in Şanlıurfa.

\section{Materials and Methods}

The hypospadias repairs were performed by two urologists who had completed their urology residency at the same clinic in a state hospital. The hypospadias patients were evaluated retrospectively. Written informed consent was obtained from all participants or their legal guardians. The research was conducted according to the principles of the World Medical Association's Declaration of Helsinki. The series consisted of 45 distal hypospadias patients aged between 2 and $24(9.5 \pm 0.5)$ years. The meatus level varied between the coronal and distal level. Ten patients were circumcised; the remaining 35, who were uncircumcised, underwent surgery for the first time. Skin chordee was observed in 35 patients. The TIPU technique was used in all patients. The characteristics of hypospadias are presented in Table 1. Additionally, the patients were evaluated using the Glans-Urethral Meatus-Shaft (GMS) score (4), representing preoperative glans size, meatal location, and degree of shaft curvature, and the hypospadias objective scoring evaluation (HOSE) score (5), indicating postoperative meatal location and shape, urinary stream, straightness of erection, and any presence of urethral fistulae.

\section{Surgical Technique (TIPU Method)}

After injecting each patient with lidocaine solution with $1 / 80.000$ adrenaline using a $26 \mathrm{G}$ injector in the operating room, two deep and parallel incisions were made in the urethral plate in the distal of the present mean. A U-shaped incision was made to preserve the urethral plate. Some subglanular tissue was excised beneath each glans wing on the sides. A 6-14 $f$ feeding catheter was placed in the urethra for diversion. Penile skin was incised from the circumcision line and degloved. A duct-shaped urethral plate located in the hypospadiac meatus was incised, encompassing the whole epithelium from the hypospadiac meatus to the tip of the penis. Urethral formation was started from the tube proximal. Polydioxanone (6/0) sutures were used for urethra formation. The first suture was done very carefully to ensure that the urethral catheter would not be

Table 1. Hypospadias characteristics of the patients

\begin{tabular}{llllll}
\hline Meatus localization & Number & $\begin{array}{l}\text { Previous } \\
\text { circumcisions }\end{array}$ & Skin chordee & $\begin{array}{l}\text { Uncircumcised skin } \\
\text { chordee }\end{array}$ & $\begin{array}{l}\text { Circumcised skin } \\
\text { chordee }\end{array}$ \\
\hline Coronal level & 21 & 5 & 17 & 14 & 3 \\
\hline Sub coronal level & 17 & 4 & 15 & 13 & 2 \\
\hline Distal penile level & 7 & 1 & 3 & 2 & 1 \\
\hline Total & 45 & 10 & 35 & 29 & 6
\end{tabular}


constricted and the new meatus would not have a stricture. The urethra was formed using a subepithelial transitive inverting continuous suturing technique. The new urethra was covered with a subdartos fascia flap prepared with paraurethral and dorsolateral tissues. During the glanduloplasty, the circumcision line was sutured with $4 / 0$ or $5 / 0$ polyglactin 910 . The penis was wrapped with a Coban bandage at medium tightness. The bandages were removed on the fourth day. The urethral catheter was removed on the seventh day and the patient's urination was checked (Figure 1,2,3,4).

\section{Results}

The GMS scores representing the preoperative penile appearance are presented in Table 2. The patients were followed up for 6-12 months. It was observed that the skin chordee recovered after deglovation during surgery. The surgical site was wrapped with Coban bandage after the surgery for four days and a feeding tube of an appropriate size was used as a urethral catheter. Each patient was followed in the hospital for seven days after the surgery. On the seventh day, the patient's urination was observed after removing the catheter; a meatal dilatator was suggested and defined and then the patient was discharged once an easy flow from the new meatus was observed after

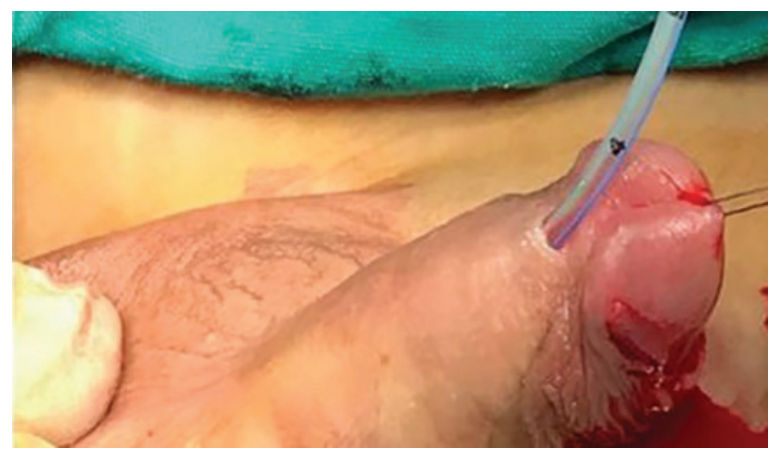

Figure 1. Coronal mea cateterization

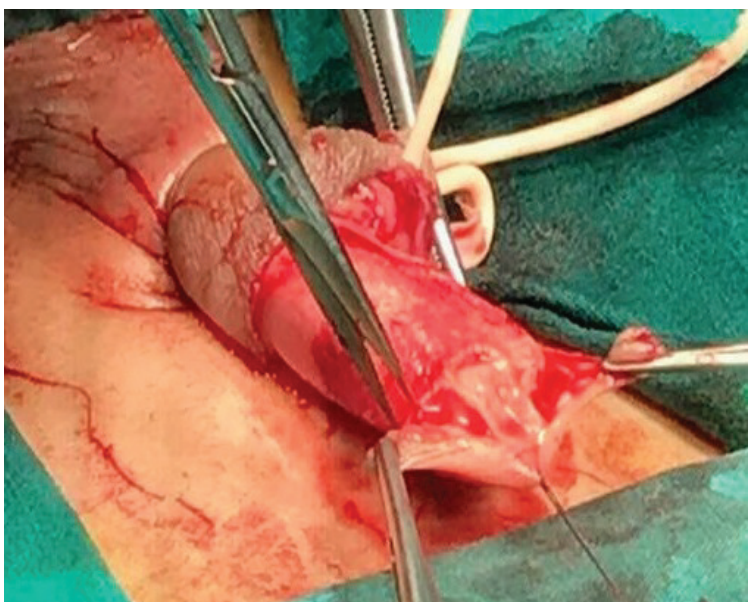

Figure 2. Urethral plate dissection

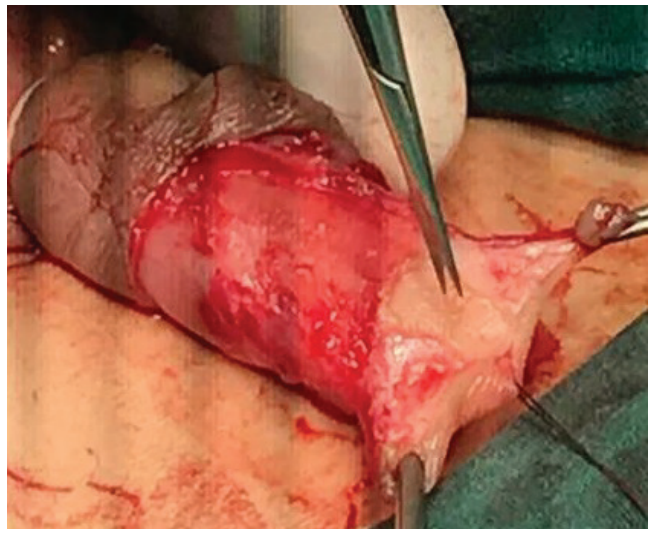

Figure 3. Urethral plate insicion

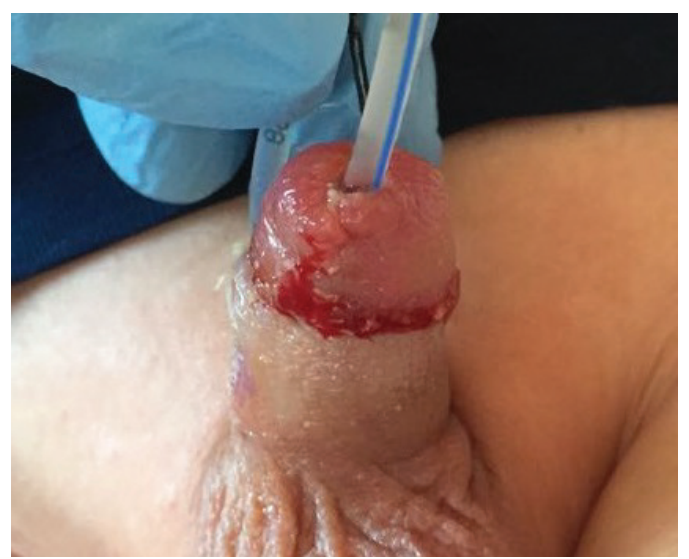

Figure 4. Postoperative image

Table 2. The Glans-Urethral Meatus-Shaft scores of patients

\begin{tabular}{lll}
\hline Score parameters & $\mathbf{n ~ ( \% )}$ & Mean score \\
\hline Glans (G) score: & & \\
$\begin{array}{l}\text { 1. Glans good size; healthy } \\
\text { urethral plate, deeply grooved }\end{array}$ & $15(55.5)$ & 1.55 \\
2. Glans adequate size; adequate & $5(11.1)$ & \\
urethral plate, grooved & 0 \\
3. Glans small in size; urethral & \\
plate narrow, some fibrosis or flat & \\
4. Glans very small; urethral plate & \\
indistinct, very narrow or flat & \\
\hline Meatus (M) score: & \\
1. Glanular & 0 \\
2. Coronal sulcus & $38(84.4)$ \\
3. Mid or distal shaft & $7(15.5)$ \\
4. Proximal shaft, penoscrotal & 0
\end{tabular}

Shaft (S) score:

1. No chordee

2. Mild $\left(<30^{\circ}\right)$ chordee $30(66.6)$

3. Moderate $\left(30-60^{\circ}\right)$ chordee $5(11.1)$

4. Severe $\left(>60^{\circ}\right)$ chordee 0 
the catheter was removed. No fistulae or strictures were observed during urination on the seventh postoperative day in any patient. To prevent bladder contractions and decrease anal itching during hospitalization, each patient was administered low-dose oxybutynin suspension and $2 \mathrm{mg} / \mathrm{mL}$ hydroxyzine hydrochloride. When the patients were being treated, it was observed that they were comfortable and did not have bladder contractions, related urethral catheter dislocations, or ana itching. The medications were administered after nearly 10 patients developed these symptoms, and the treatment was observed to allay the symptoms. Prior to being discharged, each patient or his primary caregiver was shown how use a meatal

Table 3. The hypospadias objective scoring evaluation scores of patients

\begin{tabular}{|c|c|c|}
\hline $\begin{array}{l}\text { Score parameters and score } \\
\text { values }\end{array}$ & n (\%) & Mean score \\
\hline \multicolumn{3}{|l|}{ 1.Meatal Location } \\
\hline Distal glanular $=4$ & 35 (77.7) & \multirow{4}{*}{3.77} \\
\hline Proximal glanular $=3$ & $10(22.2)$ & \\
\hline Coronal $=2$ & 0 & \\
\hline Penile shaft $=1$ & 0 & \\
\hline \multicolumn{3}{|l|}{ 2.Meatal shape } \\
\hline Vertical slit $=2$ & $40(88.8)$ & \multirow{2}{*}{1.88} \\
\hline Circular $=1$ & $5(11.1)$ & \\
\hline \multicolumn{3}{|l|}{ 3.Urinary stream } \\
\hline Single stream $=2$ & $38(84.4)$ & \multirow{2}{*}{1.84} \\
\hline Spray $=1$ & $7(15.5)$ & \\
\hline \multicolumn{3}{|l|}{ 4. Erection } \\
\hline Straigh $\mathrm{t}=4$ & 39 (86.6) & \multirow{5}{*}{3.86} \\
\hline Mild angulation $\left(<10^{0}\right)=3$ & $6(13.3)$ & \\
\hline Moderate angulation ( $>10^{0}$ but & 0 & \\
\hline$\left.<45^{0}\right)=2$ & 0 & \\
\hline \multicolumn{2}{|l|}{ Severe angulation $\left(>45^{0}\right)=1$} & \\
\hline \multicolumn{3}{|l|}{ 5.Fistula } \\
\hline None $=4$ & $44(97.7)$ & \multirow{5}{*}{3.97} \\
\hline Single-subcoronal or more distal & $1(2.2)$ & \\
\hline$=3$ & 0 & \\
\hline Single-proximal $=2$ & 0 & \\
\hline Multiple or complex $=1$ & & \\
\hline
\end{tabular}

Total score

15.32

Table 4. Postoperative general findings of patients

\begin{tabular}{ll}
\hline Operation duration & $90 \pm 10$ minutes \\
\hline Follow-up duration & Average 9.3 months \\
\hline Preoperative complication & 0 \\
\hline Catheterization duration & $7^{\text {th }}$ day \\
\hline Postoperative stricture & 2 \\
\hline Postoperative fistula & 1
\end{tabular}

dilator, as well as the capillary tube of a glass thermometer if they could not find a meatal dilatator. The patients were asked to continue meatal dilatation for one month. All patients were evaluated at the first postoperative check in the second week and at one, three, six, and 12 months postoperatively. It was observed that complications were most likely to occur in the first month. The formation of a fistula wider than coronal level was observed in a patient during the follow-up in the first month and a band of nearly $0.8 \mathrm{~mm}$ was observed to have formed in the new formed meatus. It was found that this patient had not made an effective meatal dilatation. As the patient was 20 years old and lacked a congenital left tibia and fibula, the wound recovery was not considered to be very good and he refused to undergo a second operation.

A meatal stricture was detected in the postoperative first month controls in two patients. Dilatation was performed under local anesthesia and meatal dilatation was demonstrated again. However, it was observed that the patients did not perform active meatal dilatation and meatoplasty was therefore required in the third postoperative month, as the meatal stricture recurred due to this reason. When these patients were examined in detail, it was noticed that they were blonde, fair-skinned, and had allergies. No fistulae or other complications were observed in the other patients.

The values for HOSE scores reflecting the postoperative results are presented in Table 3. It was observed that the anal itching and bladder contractions that frequently affect hypospadias patients were reduced by the postoperative drug treatment given to the patients; furthermore, patient comfort increased and the risk of urethral catheter dislocation decreased. Using a meatal dilatator or the capillary tube of a glass thermometer was observed to be beneficial in preventing the formation of meatal strictures after urethral catheter removal. The postoperative general findings are presented in Table 4.

\section{Discussion}

Most urologists tend to avoid performing hypospadias surgery, as it has a high rate of complications such as fistulae when performed in peripheral hospitals; furthermore, surgeons' experience of the procedure is limited due to the low number of hypospadias clinics across Turkiye. We performed hypospadias surgery on 45 patients in a peripheral state hospital because both surgeons performing the operations had worked in centers that took hypospadias cases during their urology training. There are no other centers with staff experienced in dealing with hypospadias in our peripheral location and our patients could not afford to seek treatment further away from home.

Distal hypospadias cases constitute 85\% of hypospadias patients. Although many surgical techniques have been defined 
for the repair of distal hypospadias, the most commonly used methods are Mathieu (flip-flap) and TIPU. A vertical meatus and conical glans cannot be created using the Mathieu method, and its reported duration of operation and complication rate are higher (6).

Multiple studies have shown that the TIPU technique has a low rate of complications and provides very successful surgical results, even in proximal hypospadias cases. In distal hypospadias in particular, the width proportion of the urethral plate to the glans is reported to be better than that achieved using other techniques. Not requiring separate skin flaps to form a vertical meatus and neourethra is one of the notable advantages of the procedure $(7,8)$. In addition to these causes, we preferred to use the TIPU method in all our patients because we have greater individual experience with it.

Our average operation duration was $90( \pm 10)$ minutes. By forming a conical glans and an angular meatus using the TIPU method, we achieved a good cosmetic appearance that more closely resembled normal anatomy.

GMS scores provide a brief and reproducible way to define the severity of hypospadias and correlates with the risk of surgical complications. Merriman et al. (4) reported that patients with a GMS score of 6 or below had fewer complications. In our study, the average $\mathrm{G}$ score was 1.55 , the average $\mathrm{M}$ score was 2.15 , the average $S$ score was 1.88 , and the total average GMS score was 5.58; these scores were found to correspond to those in the literature.

Using the HOSE system makes it easier to evaluate both the corrective operations for hypospadias and the surgical results. A HOSE score $>14$ has been reported to be acceptable for hypospadias surgery (5). Our results, which achieved an average HOSE score of 15.32, were in line with literature in terms of both surgical results and patient satisfaction. We think that our work in this study is successful as we have achieved acceptable HOSE scores based on the low preoperative GMS scores and the distal hypospadias repairs made.

In a series of 16 patients, Snodgrass reported that he encountered no meatal problems or urethral fistulae (9). The TIPU technique was applied on 148 patients in the United States and Europe, and a 7\% complication rate and good cosmetic appearances were reported (10).

Snodgrass et al. (11) reported complications in 19 out of 426 patients (4\%) (9 fistulae, 9 glans dehiscences, and one meatal stricture) after distal TIPU procedures. In a meta-analysis including 23 papers comprising 1872 TIPU repairs and 1496 Mathieu repairs published between 1994 and 2009, Wilkinson et al. (12) reported an increased incidence of urethral fistulae with the Mathieu technique (3.8\% vs 5.3\%) and meatal stenosis with the TIPU technique (3.1\% vs $0.7 \%$ ). Snodgrass later reported that the complication rate increased from 0 to $24 \%$ in patients who underwent distal TIPU between 1994 and 2009; another 25 articles reported rates of 10\% or less, which were mostly fistulae and meatal strictures (13). In our series, three of our patients (6.6\% in total) experienced complications: a urethral fistula was observed in 1 patient (2.2\%) and meatal strictures in two patients (4.4\%), in line with the literature. In their retrospective study of 492 patients, Oztorun et al. (14) compared distal hypospadias repairs and found no significant differences in the incidence of complication between Mathieu urethroplasty, and TIPU which is in line with the literature. Serrano Durbá et al. (15) found that $12 \%$ of 124 patients experienced complications following the Snodgrass procedure; nine of these were fistulae $(7.2 \%)$ and six were meatal strictures (4.8\%). Castellan et al. (16) used the Snodgrass method in 97 patients and reported that they achieved a perfect cosmetic appearance in all cases, with complications occurring in only four patients. In 300 distal hypospadias cases, Rudin et al. reported that Snodgrass TIPU was more suitable in cases where the urethral plate and glans were of normal size; when these was smaller than normal, Mathieu urethroplasty was preferred. They reported fistulae and strictures as late-developing complications (17). In our series, we observed that all complications occurred in the first postoperative month. Viseshsindh performed TIPU in 80 hypospadias patients and observed the following complications: 12 cases of fistula (15\%), three complete openings (3.75\%), and four cases of meatal stenosis (18). These complications in particular depend on hypospadias type and occur more often in proximal hypospadias cases; interestingly, age did not increase the rate of complications (18). In our series, a fistula occurred in one 20 year-old patient, but that patient had congenital anomalies. Although there were 16 patients over 10 years of age, we observed this complication only in the 20 -year-old patient. While two recent studies stated that the most important factors causing meatal stricture were technical mistakes and surgeons' lack of experience, another stated that meatal strictures and obstructions could be evaluated objectively through preoperative and postoperative uroflowmetry and were more common after TIPU $(19,20)$. Another study reported that fistulae occurred less often in dorsal dartos flaps and preputial flaps (21). We covered the neourethra with a subdartos flap in all our patients, and believe that our fistula rate is low compared to that reported in the literature.

As recorded in the literature, using a meatal dilatator once the flap is placed and after the urethral catheter is removed decreases complications in distal hypospadias repairs made using the TIPU technique. Although we had a large number of uncircumcised patients in series (22\%), we found that covering the neourethra with a dorsal or ventral subdartos flap decreased the likelihood of fistulae developing. 
In hypospadias surgery, postoperative care, follow-up, and complication management is as important as the surgical technique used. A lack of assistant doctors in peripheral hospitals and patients' postoperative follow-up being done only by nurses increases the burden on surgeons and intense shifts are required for these patients during the postoperative period. Living in peripheral areas with poor socioeconomic conditions makes it harder for patients to manage their catheters; it also makes it harder to care for patients who develop complications. Despite all these difficulties, we found that our complication rate was low and our successful surgical results were comparable to those reported in the literature.

In order to overcome these difficulties, we think that better training of assisting medical staff, particularly nurses, on issues relating to hypospadias surgery and postoperative care is required, especially in inexperienced centers. We also think that taking sufficient time to explain the procedure and aftercare to all patients, regardless of their socioeconomic condition, would make patient follow-up easier.

\section{Study Limitations}

This study is limited in that it does not include patients with proximal hypospadias, our study sample was relatively small, and we reviewed the application of only one technique in a single center.

\section{Conclusion}

Hypospadias is an anomaly that is frequently seen in pediatric urology practice and correcting it requires considerable attention and experience. TIPU is an ideal technique for surgically correcting distal hypospadias, as the complication rate is low, especially in distal hypospadias repairs, and it achieves a better cosmetic appearance. This surgical technique is preferred because it provides good results when attention is paid to basic steps that can be learned through experience in hypospadias clinics. It is also a relatively simple procedure that can be applied easily in any medical facility with an operating room and by any surgeon with sufficient experience. It should not be forgotten that surgeons become experts in specific techniques and fields by working with them regularly. Thus, although hypospadias surgery requires experience, it is a surgery which can be done quite easily in rural and suburban areas by doctors who have completed their residency in a hypospadias clinic, as long as they respect surgical rules. It is also vital that doctors inexperienced in this particular technique transfer such patients to experts. Finally, we observed that treating patients with low-dose antihistamines and anticholinergic therapy during hospitalization increased both their comfort and that of their doctors. Using a meatal dilatator or the capillary tube of a glass thermometer was observed to be beneficial in preventing meatal strictures.

\section{Ethics}

Ethics Committee Approval: Authors declared that the research was conducted according to the principles of the World Medical Association eclaration of Helsinki "Ethical Principles for Medical Research Involving Human Subjects" (amended in October 2013).

Informed Consent: It was taken.

Peer-review: Externally peer-reviewed.

\section{Authorship Contributions}

Concept: A.A., M.B., R.S., Design: A.A., M.B., R.S., Data Collection and/or Processing: A.A., M.B., R.S., M.G.S., Analysis and/or Interpretation: A.A., S.Ö., Y.E.G., Literature Research: A.A., M.B., Writing: A.A., M.G.S., M.B.

Conflict of Interest: No conflict of interest was declared by the authors

Financial Disclosure: The authors declared that this study received no financial support.

\section{References}

1. Schnack TH, Poulsen G, Myrup C, Wohlfahrt J, Melbye M. Familial coaggregation of cryptorchidism and hypospadias. Epidemiology 2010;21:109-113.

2. Zhao Z, Sun N, Mao X. Vascularization of vessel pedicle in hypospadias and its relationship to near-period complications. Exp Ther Med 2018;16:24082412.

3. Zeytun $H$, Yiğiter $M$, Salman $A B$. Retrospective comparison of surgical techniques used in the hypospadias treatment. Dicle Med J 2013;40:269274.

4. Merriman LS, Arlen AM, Broecker BH, Smith EA, Kirsch AJ, Elmore JM. The GMS hypospadias score: assessment of inter observer reliability and correlation with post-operative complications. J Pediatr Urol 2013;9:707712.

5. Holland AJ, Smith GH, Ross FI, Cass DT. HOSE: an objective scoring system for evaluating the results of hypospadias surgery. BJU Int 2001;88:255-258.

6. Oswald J, Körner I, Riccabona M. Comparison of the perimeatal based flap (Mathieu) and the tubularized incised plate urethroplasty (Snodgrass) in primary distal hypospadias. BJU Int 2000;85:725-727.

7. Arshadi H, Sabetkish S, Kajbafzadeh AM. Modified tubularized incised plate urethroplasty reduces the risk of fistula and meatal stenosis for proximal hypospadias: a report of 63 cases. Int Urol Nephrol 2017;49:2099-2104.

8. Ru W, Shen J, Tang D, Xu S, Wu D, Tao C, Chen G, Gao L, Wang X, Shen Y Width proportion of the urethral plate to the glans can serve as an appraisal index of the urethral plate in hypospadias repair. Int J Urol 2018;25:649653

9. Snodgrass W. Tubularized, incised plate urethroplasty for distal hypospadias. J Urol 1994;151:464-465.

10. Snodgrass W, Koyle M, Manzoni G, Hurwitz R, Caldamone A, Ehrlich R. Tubularised incised plate urethroplasty; results of a multicenter experience. J Urol 1996;156:839-841. 
11. Snodgrass WT, Bush N, Cost N. Tubularized incised plate hypospadias repair for distal hypospadias. J Pediatr Urol 2010;6:408-413.

12. Wilkinson DJ, Farrelly P, Kenny SE. Outcomes in distal hypospadias: a systematic review of the Mathieu and tubularized incised plate repairs. $J$ Pediatr Urol 2012;8:307-312.

13. Snodgrass W. Hypospadias. In: Wein A, Kavoussi L, Novick A. CampbellWalsh urology. 10th ed. Philadelphia, Elsevier, 2011, pp 3503-3536.

14. Oztorun K, Bagbanci S, Dadali M, Emir L, Karabulut A. A retrospective analysis of mathieu and tip urethroplasty techniques for distal hypospadias repair; A 20 year experience. Arch Esp Urol 2017;70:679-687.

15. Serrano Durbá A, Pacheco Bru JJ, Domínguez Hinarejos C, Estornell Moragues F, Nome C, Martinez Verduch M, Garcia Ibarra F. Hypospadias repair with Snodgrass' technique. Actas Urol Esp 2007;31:528-531.

16. Castellan M, Labbie A, Lince L, Gosalbez R. Versatility of Snodgrass technique for the correction of different types of hypospadias. Arch Esp Urol 2000;53:625-628.
17. Rudin luÉ, Marukhnenko DV, Garmanova TN, Să̌edov KM. The choice of method of urethroplasty in patients with distal and middle hypospadias. Urologiia 2013:92-96.

18. Viseshsindh W. Factors affecting results of hypospadias repair: single technique and surgeon. J Med Assoc Thai 2014;97:694-698.

19. Singh RB, Pavithran NM. Lessons learnt from Snodgrass tip urethroplasty: a study of 75 cases. Pediatr Surg Int 2004;20:204-246.

20. Piplani R, Aggarwal SK, Ratan SK. Role of uroflowmetry before and after hypospadias repair. Urol Ann 2018;10:52-58.

21. Tam YH, Pang KK, Wong YS, Tsui SY, Wong HY, Mou JW, Chan KW, Lee $\mathrm{KH}$. Improved outcomes after technical modifications in tubularized incised plate urethroplasty for mid- shaft and proximal hypospadias. Pediatr Surg Int 2016;32:1087-1092. 